\title{
Correlation of plasma progesterone concentrations to ovarian H-type lipase activity during pseudopregnancy in the rat
}

\author{
M. Gåfvels*, G. Bengtsson-Olivecrona $†$ and T. Olivecrona $\dagger$ \\ Department of *Physiology and Department of $\dagger$ Physiological Chemistry, University of Umeå, \\ $S$-901 87 Umeå, Sweden
}

\begin{abstract}
Summary. Conditions for extraction and assay of hepatic type (H-type) lipase from rat ovaries were studied. An alkaline buffer with protease inhibitors and detergents gave the most efficient extraction. The specificity of the assay was ascertained using antiserum to $\mathrm{H}$-type lipase from heparin perfusates of rat livers. H-type lipase activity was determined in ovarian compartments during pseudopregnancy (1-13 days) as well as during the ensuing period of luteal regression (Day 17). The activity was low in the luteal compartment immediately after ovulation, increased 6-fold to a maximum between Day 5 and Day 8 and then decreased again. This is similar to previously known changes in blood flow. There was a significant correlation between luteal H-type lipase activity and plasma progesterone regardless of luteal age. In contrast, neither the activity in the remainder of the ovary nor the activity in plasma changed during the luteal phase or correlated to plasma progesterone. Injection of heparin at the height of the luteal cycle (Day 8) caused a pronounced decrease in luteal lipase and in plasma progesterone. These studies suggest that the H-type lipase activity has an important role in luteal steroidogenesis, probably to facilitate uptake of cholesterol from lipoproteins.
\end{abstract}

Keywords: hepatic lipase; corpus luteum; progesterone; heparin; plasma; rat

\section{Introduction}

Steroid hormone-producing cells derive cholesterol for conversion into hormones from de-novo synthesis or by uptake of cholesterol carried on plasma lipoproteins. The rat corpus luteum has one of the highest known rates of steroid hormone production. Luteinized tissue from rats binds highdensity lipoprotein (HDL) particles (Christie et al., 1981; Rajkumar et al., 1985). Treatment with 4-aminopyrazolo $(3,4,-\mathrm{d})$ pyrimidine, a drug known to depress hepatic secretion of lipoprotein cholesterol without altering luteal morphology, decreased luteal cholesterol concentration and progesterone production (Andersen \& Dietschy, 1978; Christie et al., 1979). This effect was partly and dose-dependently reversed by the infusion of HDL but not low-density lipoproteins (Andersen \& Dietschy, 1978). Hence, HDL cholesterol has been proposed as the major physiological precursor in ovarian steroidogenesis (Gwynne \& Strauss, 1982). The mechanism by which the luteal cells take up the cholesterol is, however, not known.

It has been suggested that a lipase similar or identical to the hepatic heparin-releasable (H-type) lipase is involved in cholesterol uptake by ovaries and adrenals (Jansen \& Hülsmann, 1980; Jansen \& de Greef, 1981, 1988; Jansen et al., 1985). The primary structure of the enzyme is now known from its cDNA (Komaromy \& Schotz, 1987; Stahnke et al., 1987; Datta et al., 1988). The lipase is anchored to cell surfaces (Jansen \& Hülsmann, 1980). Binding to the lipase would bring lipoprotein particles in close apposition to the membrane and facilitate exchange of lipid components, as has 
been demonstrated for the related enzyme lipoprotein lipase (Stein et al., 1984). Furthermore, the lipase hydrolyses lipoprotein phospholipids, creating a relative excess of cholesterol. This acts as a driving force for net transfer of cholesterol into the cell (Jansen \& Hülsmann, 1980; Bamberger et al., 1985). The anatomical design of the corpus luteum with its rich sinusoidal vascularization (Damber et al., 1987) would favour this type of mechanism. Previous studies have established that the enzyme displays high activity in the rat ovary (Jansen \& de Greef, 1981), and is localized mainly to endothelial sites in the corpus luteum (Jansen et al., 1985; Persoon et al., 1986). A correlation to plasma progestagens during the oestrous cycle and during lactation has been noted (Jansen \& de Greef, 1981; Jansen et al., 1985). To study further whether there is a functional relation between this lipase and luteal steroidogenesis, we have examined the changes in its activities in different compartments of the ovary during pseudopregnancy and have compared them to the concentration of plasma progesterone. We have also studied the effects of heparin injection on progesterone production, since heparin is known to displace the enzyme from its endothelial binding sites into the circulating blood.

\section{Materials and Methods}

Animals. Mature female and male Sprague-Dawley rats purchased from ALAB (Sollentuna, Sweden) at the age of 34 months $(250-300 \mathrm{~g}$ body weight) were allowed to acclimatize for 2 weeks. The rats were kept at the local animal house under controlled environmental conditions $\left(20-23^{\circ} \mathrm{C}, 40-60 \%\right.$ humidity, light period $\left.0500-1900 \mathrm{~h}\right)$ and had free access to standard diet pellets (Type R3 from Ewos Co., Södertålje, Sweden) and tap water.

Pseudopregnancy. Four- and 5-day cycling rats (3-4/cage) were mated with vasectomized sterile male rats ( $1 /$ cage) according to Bartosik \& Szarkowski (1973). By the mating-induced release of prolactin the non-functional corpus luteum of the oestrous cycle is rescued to form a corpus luteum of pseudopregnancy (Gunnet \& Freeman, 1983) with a functional life-span of 12-14 days (Gåfvels et al., 1987). Day 1 is defined as the morning of the oestrous day when a characteristic vaginal plug is found (Long \& Evans, 1922). The functional batch of corpora lutea formed in this model can be identified and dissected under a stereomicroscope as described by Gåfvels et al. (1987).

Experimental procedure. Rats were killed by decapitation. In some experiments $250 \mathrm{IU}$ heparin (Lövens, Helsingborg, Sweden) were injected intraperitoneally $1 \mathrm{~h}$ earlier. Blood was collected and centrifuged in heparinized tubes. The plasma was stored at $-20^{\circ} \mathrm{C}$ until analysis of lipase activity or progesterone concentration. Ovaries were rapidly excised and placed in ice-chilled $10 \mathrm{~mm}$-phosphate, $150 \mathrm{~mm}-\mathrm{NaCl}, \mathrm{pH} 7.4$. The corpora lutea of pseudopregnancy were identified and dissected free from the remainder of the ovary.

Corpora lutea and remainders of the ovaries were homogenized using a Polytron (Kinematica Co., Luzern, Switzerland: three 10 -sec bursts at medium setting) in a buffer $(1: 10 \mathrm{w} / \mathrm{v})$ at $\mathrm{pH} 8.2$ containing $25 \mathrm{~mm}$-ammonia, $5 \mathrm{~mm}$-EDTA, $0.8 \%(\mathrm{w} / \mathrm{v})$ Triton X-100, 0.04\% (w/v) sodium dodecyl sulphate, and, per $\mathrm{ml}, 5 \mathrm{IU}$ heparin, $10 \mu \mathrm{g}$ leupeptin, $1 \mu \mathrm{g}$ pepstatin and $25 \mathrm{IU}$ Trasylol. Of several different media tested (Table 1), this one (designated Medium 4) was found to be most efficient for extraction of H-type lipase activity from rat ovaries (Table 1). The homogenate was centrifuged at $7000 \mathrm{~g}$. The clear supernatant was recovered and stored frozen at $-20^{\circ} \mathrm{C}$.

Antiserum. The antiserum used here was raised in a rabbit using H-type lipase partly purified from rat liver heparin perfusates as antigen (Wallinder et al., 1984). It has previously been used to study lipase activities in liver and plasma of rats and mice (Peterson et al., 1985, 1986; Olivecrona et al., 1986). These studies demonstrate that H-type lipase activity is inhibited more than $95 \%$ by this antiserum, whereas lipoprotein lipase is not inhibited.

Determination of H-type lipase activity. The assay described by Hernell et al. (1975) was used: 0-20 (usually 10) $\mu \mathrm{l}$ of sample and distilled water to make $50 \mu \mathrm{l}$ were added to $150 \mu \mathrm{l}$ of an assay mixture with a gum arabic-stabilized emulsion of $\left[{ }^{3} \mathrm{H}\right]$ oleic acid-labelled triolein (about 540000 d.p.m.), bovine serum albumin (4\% w/v: Sigma, St Louis, $\mathrm{MO}, \mathrm{USA}$ ) and Tris $(0.1 \mathrm{M})$. The $\mathrm{NaCl}$ concentration in the final assay mixture was $1 \mathrm{M}$, the $\mathrm{pH}$ was $8 \cdot 5$. Incubation was for $60 \mathrm{~min}$ at $25^{\circ} \mathrm{C}$. The released fatty acids were extracted as described by Belfrage \& Vaughan (1969), and their radioactivity was determined by liquid scintillation counting. Lipase activity is expressed in milliunits $(1 \mathrm{mU}=1 \mathrm{nmol}$ fatty acid released per $\mathrm{min}$ ). The assay was linear over the range of sample volumes used (Fig. 1). In some experiments the tissue homogenates were incubated for $2 \mathbf{h}$ on ice with equal volumes of the antiserum to H-type lipase or a corresponding pre-immune serum. These experiments showed that the lipase activity was always inhibited more than $80 \%$ and usually more than $90 \%$ by the antiserum (see Table I and Fig. 1). Previous studies have shown that, under the conditions used, lipoprotein lipase is inhibited more than $95 \%$ by $1 \mathrm{M}-\mathrm{NaCl}$ (Bengtsson \& Olivecrona, 1983).

Determination of plasma progesterone. The concentration of plasma progesterone was determined using radioimmunoassay as described by Orczyk et al. (1979) and Gåfvels et al. (1987). The sensitivity of the assay was $5 \mathrm{pg} / \mathrm{ml}$ and intra- and inter-assay coefficients of variation were $5.0 \%$ and $15.0 \%$ respectively. 
Statistics. Values are given as mean \pm s.e.m. Statistics were performed using the Mann-Whitney U-test (Siegel, 1956). Correlations were calculated with Spearman's rank correlation coefficient (Siegel, 1956). A $P$ value of $<0.05$ was considered significant.

\section{Results}

The first step in this study was to establish suitable conditions to extract and assay ovarian lipase. When the tissue was homogenized in phosphate-buffered saline containing heparin and protease inhibitors and the homogenate was then centrifuged a high lipase activity was recovered in the supernatant (Table 1). Addition of detergents did not increase the extracted activity, and addition of glycerol decreased the activity. However, a dilute ammonia buffer at $\mathrm{pH} 8.2$ proved even more efficient and was therefore adopted for the further experiments (Table 1). The activity measured in the lipase assay increased linearly with the amount of supernatant used (Fig. 1). The assay medium contained $1 \mathrm{M}-\mathrm{NaCl}$, which suppresses lipoprotein lipase (Bengtsson \& Olivecrona, 1983). The lipase activity extracted by the various buffers tested (Table 1) was in all cases inhibited more than $90 \%$ by preincubation with antibodies to H-type lipase. We conclude that the conditions used give an efficient and rather selective measurement of $\mathbf{H}$-type lipase in ovarian tissue.

Table 1. Extraction of H-type lipase from rat ovaries by different media

\begin{tabular}{lccccc}
\hline & \multicolumn{2}{c}{ Lipase activity (mU/ml homogenate) } \\
\cline { 2 - 3 } & \multicolumn{2}{c}{ Corpus luteum } & & \multicolumn{2}{c}{ Remainder of ovary } \\
\cline { 2 - 3 } \cline { 6 - 6 } & Control & $\begin{array}{c}\text { Anti- } \\
\text { HL }\end{array}$ & & Control & $\begin{array}{c}\text { Anti- } \\
\text { HL }\end{array}$ \\
\hline Medium 1 & 52.3 & 2.8 & & 10.4 & $1 \cdot 1$ \\
Medium 2 & $25 \cdot 1$ & 1.7 & & 11.8 & 1.4 \\
Medium 3 & $49 \cdot 3$ & 2.6 & & 11.4 & 0.9 \\
Medium 4 & 70.1 & 1.6 & & 13.0 & 0.8 \\
\hline
\end{tabular}

Tissues from several rats were pooled and equal aliquants were homogenized in different media. The homogenates were incubated on ice with either an antiserum to rat hepatic lipase (Anti-HL) or a corresponding nonimmune serum (Control).

Medium I = $20 \mathrm{~mm}$-Tris- $\mathrm{HCl} \mathrm{pH} \mathrm{7.4,0} 15 \mathrm{M}-\mathrm{NaCl}$ and per $\mathrm{ml} 5 \mathrm{IU}$ heparin, $10 \mu \mathrm{g}$ leupeptin, $1 \mu \mathrm{g}$ pepstatin and 25 IU Trasylol; Medium $2=$ as Medium 1, but with $20 \%$ glycerol added; Medium $3=$ as Medium 1, but with $0.1 \%$ Triton X-100 and $0.01 \%$ SDS added; Medium $4=$ as Medium 3, but $0.025 \mathrm{M}$-ammonia buffer $\mathrm{pH} 8.2$ instead of Tris- $\mathrm{HCl}$ and $\mathrm{NaCl}$.

In the assay used by Jansen et al. (1985) a substantial lipase activity that could not be inhibited by antibodies to $\mathrm{H}$-type lipase or by $1 \mathrm{M}-\mathrm{NaCl}$ was noted, sometimes accounting for more than $50 \%$ of total lipase activity. The characteristics of this activity suggest that it is due to an enzyme related to the hormone-sensitive lipases of adipose tissue and adrenals (Holm et al., 1987). In recent studies (Holm et al., 1987, 1988) both hormone-sensitive lipase mRNA and protein have been directly demonstrated in rat ovaries. The hormone-sensitive lipases are inhibited by detergents (Belfrage et al., 1977). In our study we extracted the ovaries with a detergent-containing buffer. This gave high yield of $\mathrm{H}$-type lipase, but would be expected to suppress hormone-sensitive lipase. In accord with this we noted low residual activity (see Fig. 1) after immunoinhibition with antiserum to H-type lipase. 


\section{Lipase activity during pseudopregnancy}

The lipase activity in corpora lutea was low on the morning after ovulation (Day 1, Fig. 2a), rose rapidly to Day 5, remained high for 3 days, and then decreased again. At all times the activity was inhibited more than $90 \%$ by antiserum to H-type lipase (data not shown). The activity of H-type lipase in the remainder of the ovary was considerably lower than in the corpus luteum and did not change significantly during pseudopregnancy (Fig. 2b). Also, for the remainder of the ovary the lipase activity was inhibited $80-90 \%$ by antiserum to H-type lipase. The lipase was apparently therefore of the same type as in the corpus luteum but its regulation differed. The ratio of lipase activity in the corpus luteum compared to that in the remainder of the ovary shows a pattern similar to the changes in enzyme activity displayed for the corpus luteum (Fig. 3). This lipase activity ratio is rather similar to the ratio for capillary blood flow distribution between the active corpora lutea and the remainder of the ovary as recorded in another study (Norjavaara et al., 1987) and indicated by bars in Fig. 3.

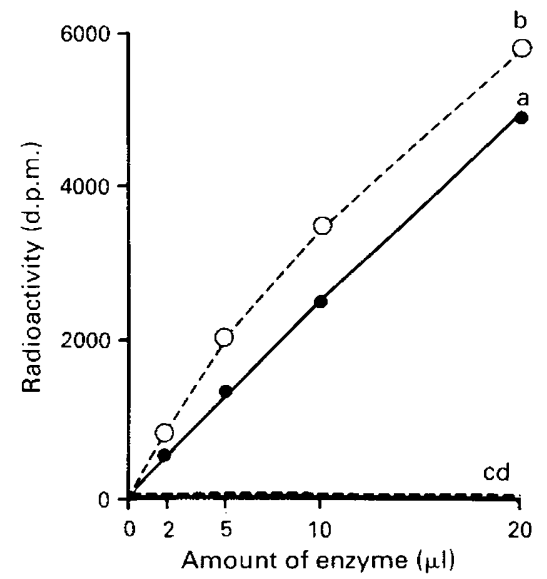

Fig. 1. Linearity and specificity of the lipase assay. Homogenates of corpus luteum (a) or of liver (b) were incubated for $2 \mathrm{~h}$ on ice with equal volumes of antiserum (c and $\mathrm{d}$ ) to rat hepatic lipase or with a corresponding nonimmune serum ( $a$ and $b$ ). Then, different volumes of the mixtures were assayed for lipase activity.

\section{Effects of heparin}

These experiments were done on Day 8 of pseudopregnancy, i.e. the time of maximal lipase activity (and maximal progesterone production). Injection of $250 \mathrm{IU}$ heparin $1 \mathrm{~h}$ before the animals were killed decreased the lipase activity by about $75 \%$ in the corpora lutea (Fig. 2a, values indicated by arrow) and by about $50 \%$ in the remainder of the ovary (Fig. 2b, values indicated by arrow). The injection of heparin also resulted in an acute decrease in plasma progesterone concentrations from $144 \pm 13 \mathrm{ng} / \mathrm{ml}$ to $101 \pm 3 \mathrm{ng} / \mathrm{ml}(P<0 \cdot 05)$. On the other hand, the activity of H-type lipase in plasma increased about 50 -fold to $114 \pm 7 \mathrm{mU} / \mathrm{ml}$.

\section{Lipase activity in plasma}

It has been suggested that H-type lipase is produced only in the liver, and is transported to adrenals and ovaries. We therefore compared the activity of $\mathrm{H}$-type lipase in plasma at Day 8 of pseudopregnancy to that in ovariectomized female rats and in male rats. The H-type lipase activity was low in plasma and did not differ significantly between the groups tested $(2 \cdot 2 \pm 0 \cdot 1$, 


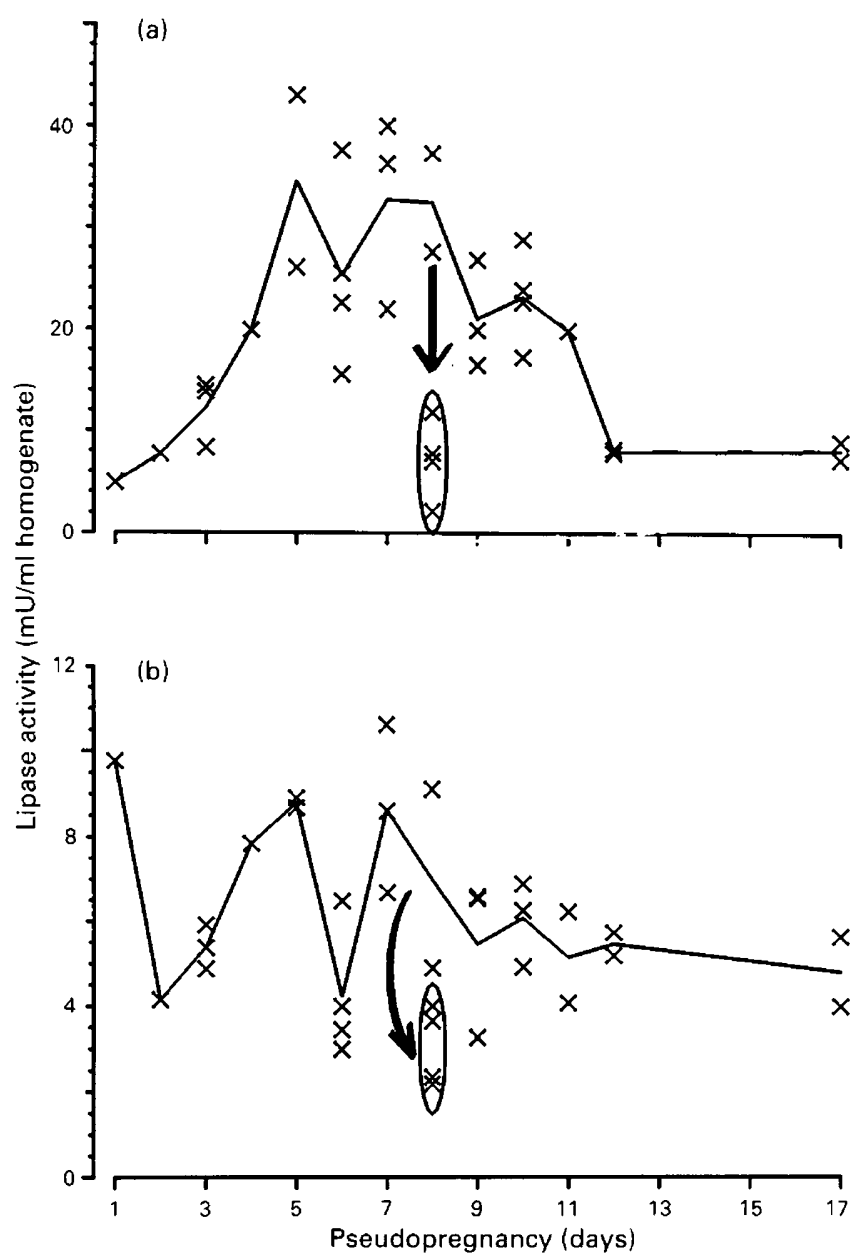

Fig. 2. Lipase activities in homogenates from (a) corpora lutea and (b) the remainder of the ovary at different times of pseudopregnancy. The corpora lutea and remainders of the ovaries were pooled from single rats except for Day 1 when tissues from 5 rats had to be pooled to generate enough tissue. Four rats were given 250 IU heparin i.p. $1 \mathrm{~h}$ before they were killed on the 8th day of pseudopregnancy (values encircled). The arrow indicates the decrease in lipase activity that resulted from the heparin injection.

$2 \cdot 0 \pm 0 \cdot 2,2 \cdot 2 \pm 0 \cdot 1 \mathrm{mU} / \mathrm{ml}$ in the three groups respectively, means \pm s.e.m. of $5-6$ rats in each group).

\section{Correlation between lipase activity and plasma progesterone}

The pattern for H-type lipase activity in the corpus luteum (Fig. 2a) was strikingly similar to the plasma progesterone concentrations recorded in another study (Norjavaara et al., 1987), with one exception; after the period of luteal progesterone production (Day 17) substantial H-type lipase activity was still present in the corpus luteum.

The close relation beween lipase activity in the corpus luteum and plasma progesterone concentration was confirmed by direct measurements of each in the same animals (Fig. 4a). There was a significant correlation $(r=0.73, P<0.001)$. In contrast, there was no significant correlation 


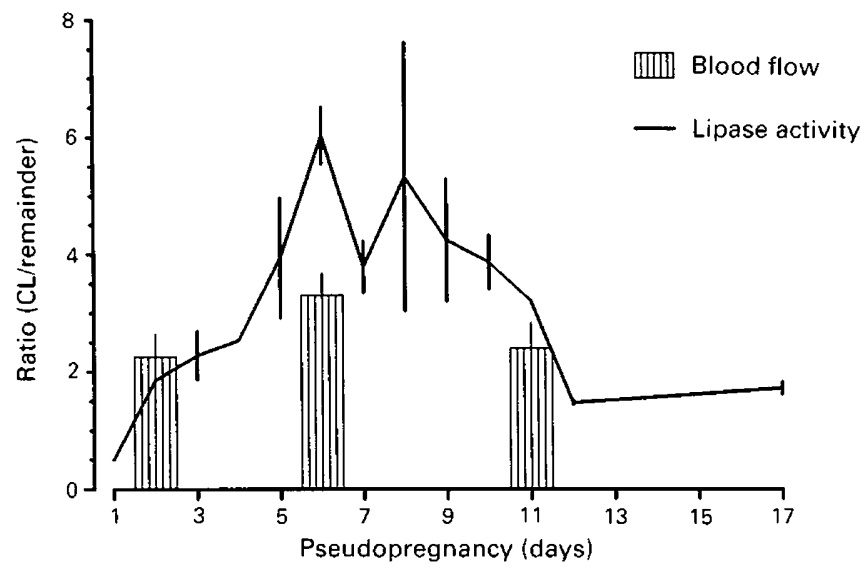

Fig. 3. Ratio of lipase activity in the corpus luteum and in the remainder of the ovary at different times of pseudopregnancy (-). The vertical bars at Days 2, 6 and 11 show the ratio of capillary blood flow in the corpus luteum to that in the remainder of the ovary as measured with radioactive microspheres (data obtained from Norjavaara et al., 1987).

between the lipase activity in the remainder of the ovary and plasma progesterone values (Fig. $4 \mathrm{~b}$; $r=0.17, P>0.05$ ).

\section{Discussion}

The present study confirms previous reports that, in the rat, ovarian H-type lipase activity is distributed mainly in the corpus luteum (Jansen \& de Greef, 1981), and that the activity varies during the luteal cycle in parallel with plasma progesterone concentrations (Jansen et al., 1985). These findings suggest a close relation between the function of this enzyme and steroidogenesis.

Jansen et al. (1985) reported that the pattern of H-type lipase activity in the corpus luteum during the oestrous cycle was similar to the pattern of serum progesterone concentrations. The changes in lipase activity were, however, rather small in that study, less than 2-fold. The changes we found during pseudopregnancy were larger; a 6-fold increase was noted from Day 1 to Day 5. Jansen \& de Greef (1981) noted a 3-fold higher lipase activity in whole ovaries of pseudopregnant rats compared to controls. We demonstrate that it is only the activity in the corpus luteum that increases during pseudopregnancy; the activity in the remainder of the ovary was unchanged. The changes in plasma progesterone are also greater during pseudopregnancy than during the normal cycle (Pepe \& Rothchild, 1974; Nequin et al., 1979). All these studies indicate a parallelism between changes in ovarian H-type lipase activity and steroidogenesis. While this work was in progress, Jansen \& de Greef (1988) reported a detailed study on the impact of lowering ovarian H-type lipase activity on cholesterol metabolism in the ovaries. For this they used hormonal manipulations, metabolic inhibitors as well as immunoinhibition. This study gives additional support to the hypothesis that $\mathrm{H}$-type lipase is involved in ovarian cholesterol homeostasis.

Injection of heparin caused an acute decrease in plasma progesterone concentrations. The most direct interpretation of this is that displacement of $\mathrm{H}$-type lipase into the circulating blood deprived the ovary of a means for acquiring cholesterol substrate for steroidogenesis. Other interpretations are, however, also possible. It has been reported that incubation of ovarian plasma membrane preparations with heparin inhibits luteinizing hormone $(\mathbf{L H})$-sensitive adenylate cyclase (Solomon \& Amsterdam, 1977). The heparin injection may thus have acutely deprived the corpus luteum of its endogenous LH support. 


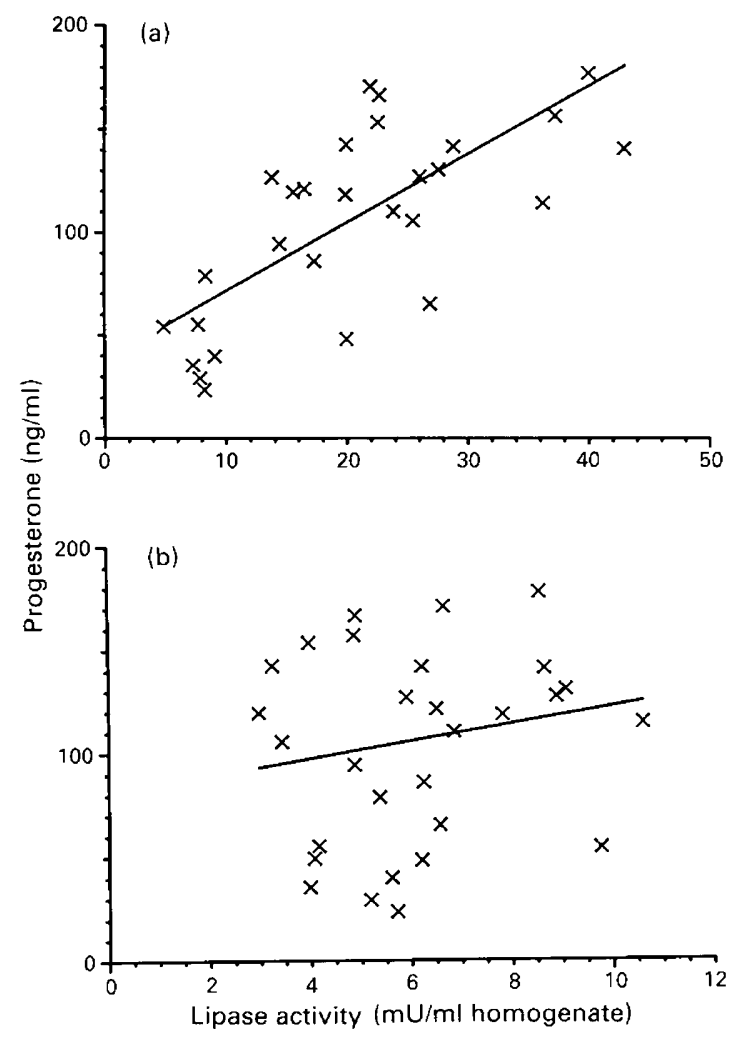

Fig. 4. Relation between plasma progesterone and the lipase activities in corpus luteum (a) and in the remainder of the ovary (b). The correlation coefficients were 0.73 (a) and 0.17 (b).

Studies using immunofluorescence have shown that $\mathrm{H}$-type lipase is located at the luteal vascular endothelium (Persoon et al., 1986). As seen in Fig. 3 the distribution of H-type lipase activity between the corpus luteum and the remainder of the ovary is rather similar to the distribution of blood flow recorded in another study (Norjavaara et al., 1987). The corpus luteum has the highest blood flow among all rat organs and the physiological function of this has not yet been established (Gåfvels, 1987). It has been calculated that about $60 \%$ of the luteal cell area faces capillaries and that the mean diffusion distance between capillaries and luteal cells in corpora lutea of Day-16 pregnant rats is only $0.5 \mu \mathrm{m}$ (Dharmarajan et al., 1985). The combination of high blood flow and high $\mathrm{H}$-type lipase activity provides a mechanism for assimilation of lipids from plasma lipoproteins for luteal metabolism. It has been suggested that a major function of the $\mathbf{H}$-type lipase is to effect uptake of cholesterol from lipoproteins, primarily HDL (Jansen \& Hülsmann, 1980; Jansen \& de Greef, 1981; Jansen et al., 1985; Jansen \& de Greef, 1988). Pretreatment of LDL particles with H-type lipase has been shown to increase LDL receptor-mediated cholesterol uptake to human macrophages twice, suggesting a co-operation between the action of $\mathrm{H}$-type lipase and receptor-mediated cholesterol uptake (Aviram et al., 1988). In the present study, total cholesterol uptake (receptor dependent + receptor-independent uptake) as well as total progestagen production of the corpus luteum in relation to changes in H-type lipase activity was not measured. During the luteolytic period the corpus luteum of pseudopregnancy has been shown to convert progesterone to increasing amounts of $20 \alpha$-dihydroprogesterone by an increased activity of luteal $20 \alpha$-hydroxysteroid dehydrogenase. By this mechanism the secretion of the progestationally inactive metabolite $20 \alpha$-dihydroprogesterone can be maintained for several days although progesterone 
secretion has ceased (Lamprecht et al., 1975; Kim \& Greenwald, 1984). As seen in the present study, this corresponds to a period when luteal H-type lipase activity is declining (Day 10-17; Fig. 2). During luteolysis cholesterol may be delivered to luteal cells by the alternative pathways discussed by Jansen \& de Greef (1988). Therefore, one possibility is that high luteal H-type lipase activity is seen only during a period of high endogenous progesterone production. In that case H-type lipase may constitute a (progesterone-dependent?) part of the luteotrophic process, as discussed by Rothchild (1981). It cannot be ruled out that $\mathbf{H}$-type lipase is also involved in delivery of other lipids, perhaps fatty acids, important to luteal energy metabolism and the synthesis of luteal prostaglandins.

Doolittle et al. (1987) have suggested that adrenal H-type lipase protein is made in the liver and transported to the adrenal. Analogy suggests that the same is the case for the ovarian enzyme, but this remains to be directly tested. There are pieces of evidence which are difficult to reconcile with a transport from liver as the sole source of ovarian lipase activity. The activity per amount of tissue is as high in corpus luteum as in the liver. Heparin which is supposed to dislodge the enzyme from its endothelial binding sites did not release all the lipase; $25-50 \%$ remained in the tissue. Similar results have been obtained by Jansen \& de Greef (1981). Although the corpus luteum has a high blood flow, the high H-type lipase activity cannot be explained only on the basis of a high capillary density; uptake from blood implies binding sites not present in most other tissues. Furthermore, the plasma $\mathrm{H}$-type lipase activity did not differ significantly between ovariectomized and male rats on the one hand and Day- 8 pseudopregnant rats on the other. If the enzyme was transported by a 'liver-ovarian' pathway one would have expected an increase in plasma H-type lipase activity during the period with maximal activities in the ovary.

This study indicates that H-type lipase has an important role in ovarian steroidogenesis. At the very least it demonstrates that the enzyme is highly regulated in the ovary. An important question that remains is whether the enzyme activity is regulated by changes in production of the enzyme itself within the ovary, or by changes in the expression of some endothelial binding site for uptake of the enzyme from blood.

We thank Ms Ann-Sof Jakobsson for skilful technical assistance. This study was supported by grants from the Swedish Medical Research Council (13X-727), the Lars Hierta Foundation, the Åke Wiberg Foundation, the Swedish Medical Association, and the Medical Faculty, University of Umeå, Sweden.

\section{References}

Andersen, J.M. \& Dietschy, J.M. (1978) Relative importance of high and low density lipoproteins in the regulation of cholesterol synthesis in the adrenal gland, ovary, and testis of the rat. J. biol. Chem. 253, 9024-9032.

Aviram, M., Bierman, E.L. \& Chait, A. (1988) Modification of low density lipoprotein by lipoprotein lipase or hepatic lipase induces enhanced uptake and cholesterol accumulation in cells. J. biol. Chem. 263, $15416-15422$.

Bamberger, M., Lund-Katz, S., Phillips, M.C. \& Rothblat, G.H. (1985) Mechanism of the hepatic lipase induced accumulation of high-density lipoprotein cholesterol by cells in culture. Biochemistry, N.Y. 24, 3693-3701.

Bartosik, D. \& Szarkowski, D.H. (1973) Progravid phase of the rat reproductive cycle: Day to day changes in peripheral plasma progestin concentrations. Endocrinology 92, 949-952.

Belfrage, P. \& Vaughan, M. (1969) Simple liquid-liquid partition system for isolation of labeled oleic acid from mixtures with glycerides. J. Lipid Res. 10, 341-344.
Belfrage, P., Jergil, B., Strålfors, P. \& Tornqvist, H. (1977) Hormone-sensitive lipase of rat adipose tissue: identification and some properties of the enzyme protein. FEBS Lett. 75, 259-264.

Bengtsson, G. \& Olivecrona, T. (1983) The effects of $\mathrm{pH}$ and salt on the lipid binding and enzyme activity of lipoprotein lipase. Biochim. Biophys. Acta 751, 254-259.

Christie, M.H., Strauss, J.F. \& Flickinger, G.L. (1979) Effect of reduced blood cholesterol on sterol and steroid metabolism by rat luteal tissue. Endocrinology 105, 92-98.

Christie, M.H., Gwynne, J.T. \& Strauss, J.F. (1981) Binding of human high density lipoproteins to membranes of luteinized rat ovaries. J. Steroid Biochem. 14, 671-678.

Damber, J.-E., Cajander, S., Gåfvels, M. \& Selstam, G. (1987) Blood flow changes and vascular appearance in preovulatory follicles and corpora lutea in immature pregnant mare serum gonadotropin-treated rats. Biol. Reprod. 37, 651-658. 
Datta, S., Luo, C.-C., Li, W.-H., van Tuinen, P., Ledbetter, D.H., Brown, M.A., Chen, S.-H., Liu, S.-W. \& Chan, L. (1988) Human hepatic lipase. Cloned cDNA sequence, restriction enzyme fragment length polymorphisms, chromosomal localization, and evolutionary relationships with lipoprotein lipase and pancreatic lipase. J. biol. Chem. 263, 1107-1110.

Dharmarajan, A.M., Bruce, N.W. \& Meyer, G.T. (1985) Quantitative ultrastructure characteristics relating to transport between luteal cell cytoplasm and blood in the corpus luteum of the pregnant rat. Anat. Rec. 172, 87-99.

Doolittle, M.H., Wong, H., Davis, R.C. \& Schotz, M.C. (1987) Synthesis of hepatic lipase in liver and extrahepatic tissues. J. Lipid Res. 28, 1326-1334.

Gåfvels, M. (1987) Blood flow and metabolism in the corpus luteum of the rat ovary. In vivo and in vitro studies on the ovarian luteal and follicular compartment of the rat. Ph.D. thesis, Umea University Medical Dissertations, New Series, No. 186.

Gåfvels, M., Selstam, G. \& Damber, J.-E. (1987) Influence of oxygen tension and substrates on basal and luteinizing hormone stimulated progesterone production and energy metabolism by isolated corpora lutea of adult pseudopregnant rats. Acta physiol. scand. 130, 465-482.

Gunnet, J.W. \& Freeman, M.E. (1983) The matinginduced release of prolactin: $A$ unique neuroendocrine response. Endocrine Rev. 4, 44-61.

Gwynne, J.T. \& Strauss, J.F. (1982) The role of lipoproteins in steroidogenesis and cholesterol metabolism in steroidogenic glands. Endocrine Rev. 3, 299-329.

Hernell, O., Egelrud, T. \& Olivecrona, T. (1975) Serumstimulated lipases (lipoprotein lipases). Immunological crossreaction between the bovine and the human enzymes. Biochim. Biophys. Acta 381, 233-241.

Holm, C., Belfrage, P. \& Fredrikson, G. (1987) Immunological evidence for the presence of hormonesensitive lipase in rat tissues other than adipose tissue. Biochem. Biophys. Res. Commun. 148, 99-105.

Holm, C., Kirchgessner, T.G., Svenson, K.L., Fredrikson, G., Nilsson, S., Miller, C.G., Shively, J.E., Heinzmann, C., Sparkes, R.S., Mohandas, T., Lusis, A.J., Belfrage, P. \& Schotz, M.C. (1988) Hormone-sensitive lipase: Sequence, expression, and chromosomal localization to cent-q13.3. Science, N.Y. 241, 1503-1506.

Jansen, H. \& Hülsmann, C. (1980) Heparin-releasable (liver) lipase(s) may play a role in the uptake of cholesterol by steroid-secreting tissue. TIBS, October, pp. 265-268.

Jansen, H. \& de Greef, W.J. (1981) Heparin-releasable lipase activity of rat adrenals, ovaries and testes. Biochem. J. 196, 739-745.

Jansen, H. \& de Greef, W.J. (1988) L-type lipase activity in ovaries of superovulated rats. Relation to cholesterol homeostasis. Molec. cell. Endocrinol. 57, 7-15.

Jansen, H., de Greef, W.J. \& Uilenbroek, J.T.J. (1985) Localization of the liver-type lipase in rat ovaries and its activity during the oestrous cycle and lactation. Molec. cell. Endocrinol. 42, 253-258.

Kim, I. \& Greenwald, G.S. (1984) Further studies on in vitro steroidogenesis by luteal cells from long-term hypophysectomized rats. Biol. Reprod. 30, 824-832.
Komaromy, M.C. \& Schotz, M.C. (1987) Cloning of rat hepatic lipase cDNA: Evidence for a lipase gene family. Proc. natn. Acad. Sci. USA 84, 1526-1530.

Lamprecht, S.A., Herlitz, H.V. \& Ahren, K.E.B. (1975) Induction by $\mathrm{PGF}_{2 \alpha}$ of $20 \alpha$-hydroxysteroid dehydrogenase in first generation corpora lutea of the rat. Molec. cell. Endocrinol. 3, 273-282.

Long, J.A. \& Evans, H. (1922) The oestrous cycle in the rat and its associated phenomena. Mem. Univ. Calif. Vol. 6, 1-48.

Nequin, L.N., Alvarez, J. \& Schwartz, N.B. (1979) Measurement of serum steroid and gonadotropin levels and uterine and ovarian variables throughout 4 day and 5 day estrous cycles in the rat. Biol. Reprod. 20, 659-670.

Norjavaara, E., Olofsson, J., Gåfvels, M. \& Selstam, G. (1987) Redistribution of ovarian blood flow after injection of human chorionic gonadotropin and luteinizing hormone in the adult pseudopregnant rat. Endocrinology 120, 107-114.

Olivecrona, T., Bengtsson-Olivecrona, G., Chernick, S.S. \& Scow, R.O. (1986) Effect of combined lipase deficiency (cld/cld) on hepatic and lipoprotein lipase activities in liver and plasma of newborn mice. Biochim. Biophys. Acta 876, 243-248.

Orczyk, G.P., Hichens, M., Arth, G. \& Behrman, H.R. (1979) Progesterone and 20a-dihydroprogesterone. In Methods of Hormone Radioimmunoassay, 2nd edn, pp. 701-713. Eds B. M. Jaffe \& H. R. Behrman. Academic Press, New York.

Pepe, G.J. \& Rothchild, I. (1974) A comparative study of serum progesterone levels in pregnancy and in various types of pseudopregnancy in the rat. Endocrinology 95, 275-279.

Persoon, N.L.M., Hülsmann, W.C. \& Jansen, H. (1986) Localization of the salt-resistant heparin-releasable lipase in the rat liver, adrenal and ovary. Eur. J. Cell Biol. 41, 134-137.

Peterson, J., Olivecrona, T. \& Bengtsson-Olivecrona, G. (1985) Distribution of lipoprotein lipase and hepatic lipase between plasma and tissues: Effect of hypertriglyceridemia. Biochim. Biophys. Acta 837, 262-270.

Peterson, J., Bengtsson-Olivecrona, G. \& Olivecrona, T. (1986) Mouse preheparin plasma contains high levels of hepatic lipase with low affinity for heparin. Biochim. Biophys. Acta 878, 65-70.

Rajkumar, K., Couture, R.L. \& Murphy, B.D. (1985) Binding of high-density lipoproteins to luteal membranes: the role of prolactin, luteinizing hormone, and circulating lipoproteins. Biol. Reprod. 32, $546-555$.

Rothchild, I. (1981) The regulation of the mammalian corpus luteum. Recent Prog. Horm. Res. 37, 183-298.

Siegel, S. (1956) Non-parametric Statistics for the Behavioral Sciences. McGraw-Hill Hogakusha, Tokyo.

Solomon, Y. \& Amsterdam, A. (1977) Heparin: a potent inhibitor of ovarian luteinizing hormone-sensitive adenylate cyclase. FEBS Lett. 83, 263-266.

Stahnke, G., Sprengel, R., Augustin, J. \& Will, H. (1987) Human hepatic triglyceride lipase: cDNA cloning, amino acid sequence and expression in a cultured cell line. Differentiation 35, 45-52.

Stein, O., Halperin, G., Leitersdorf, E., Olivecrona, T. \& 
Stein, Y. (1984) Lipoprotein lipase mediated uptake of non-degradable ether analogues of phosphatidylcholine and cholesteryl ester by cultured cells. Biochim. Biophys. Acta 795, 47-59.
Wallinder, L., Peterson, J., Olivecrona, T. \& BengtssonOlivecrona, G. (1984) Hepatic and extrahepatic uptake of intravenously injected lipoprotein lipase. Biochim. Biophys. Acta 795, 513-524.

Received 26 October 1988 